\title{
Comparison of a commercial ELISA system with restriction endonuclease analysis for typing herpes simplex virus
}

\author{
KJ SMITH, CR ASHLEY, ${ }^{*}$ JM DARVILlE, J HARBOUR, ${ }^{*}$ APCH ROOME* \\ From the Department of Virology, Bristol Royal Infirmary, Marlborough Street, Bristol BS2 8HW
}

SUMMARY Isolates of herpes simplex virus which had previously been typed by restriction enzyme analysis were typed again with a commercial ELISA system using polyclonal antibodies. There was complete correlation between the two techniques. Although restriction is more precise and definitive, when typing only is required the simplicity of ELISA makes it the preferred technique.

For a long time the existence of two variants of herpes simplex virus (HSV), differentiated on clinical grounds, has been apparent. More recently, methods of typing such as plaque morphology, 'differential neutralisation, ${ }^{2}$ immunoperoxidase staining, ${ }^{3}$ DNA density analysis, ${ }^{4}$ guanine plus cytosine content, ${ }^{5}$ and the formation of intranuclear tubular structures $^{6}$ have been described. These methods are generally accurate and satisfactory, but are tedious, time consuming, or costly.

The types of HSV are more definitively differentiated by analysis of the viral polypeptides ${ }^{7}$ and by restriction enzyme analysis of the viral DNA. ${ }^{8}$ The latter technique especially is highly precise; it can not only differentiate the types but also the subtypes of HSV and thus is useful in studying the epidemiology of these infections..$^{10-12}$ Nevertheless, although it has been miniaturised and simplified ${ }^{13}$ to permit the typing of many isolates at low cost, it is not sufficiently simple for use in a routine virus laboratory with limited facilities. Therefore, when only typing rather than subtyping is required, other methods may be more suitable.

The cross reactivity between the two types of HSV, which confuses conventional serotyping, may be eliminated by the use of antisera extensively absorbed against heterotypic virus or by the development of monoclonal antibodies, which have now been raised against epitopes which are largely both type specific and type universal. ${ }^{14}$ However,

*Present address: Public Health Laboratory, Myrtle Road, Kingsdown, Bristol BS2 8EL

Accepted for publication 25 April 1984 use of such defined reagents may not be necessary. We have evaluated a commercial enzyme linked immunosorbent assay (ELISA) kit based on the differential reactivity of homotypic and heterotypic HSV isolates of immunoglobulin purified from polyclonal antibodies raised against HSV 1 and 2 and have compared it with restriction endonuclease typing.

\section{Material and methods}

\section{VIRUSES}

HSV standard type strains $17 \mathrm{syn}^{+}$SV (type 1) and HG 52 (type 2) were kindly provided by Mr J Lang of the Institute of Virology, Glasgow. The Bristol standard strains of SC 16 (type 1) and AR 15 (type $2)^{15}$ had been isolated and typed in this laboratory. These four strains had also been typed by restriction endonuclease analysis. ${ }^{13}$

Isolates of virus from single clinical specimens from 39 patients taking part in a trial of topical acyclovir for primary or recurrent genital herpes were made in human embryo fibroblast cells or Vero cells. In all cases virus for typing by either method was harvested from cells showing complete cytopathic effect, and usually both tests were carried out on the same sample.

\section{RESTRICTION ENDONUCLEASE TYPING}

All HSV isolates were typed by the method of Darville, ${ }^{13}$ which is outlined below.

Virus was grown and labelled with ${ }^{32} \mathrm{P}$ (Amer-

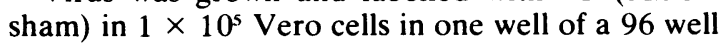
micro cell culture plate (Linbro). On the develop- 
Table 1 Typing by ELISA of two standard strains of herpes simplex virus type 1 (SC 16 and 17 syn $^{+}$SV) and two of type 2 ( $A R 15$ and $H G 52$ )

\begin{tabular}{|c|c|c|c|c|c|c|c|c|}
\hline \multirow[t]{3}{*}{ Virus } & \multicolumn{8}{|c|}{ Optical densities on coating immunoglobulin } \\
\hline & \multicolumn{2}{|l|}{ HSV 1} & \multicolumn{2}{|l|}{ HSV 2} & \multicolumn{2}{|l|}{ Control } & \multirow{2}{*}{$\frac{H S V 1}{H S V 2}$} & \multirow[t]{2}{*}{ Type } \\
\hline & Measured & Corrected & Measured & Corrected & Measured & Corrected & & \\
\hline $\begin{array}{l}\text { SC } 16 \\
17 \text { syn }^{+} \text {SV } \\
\text { AR } 15 \\
\text { HG } 52\end{array}$ & $\begin{array}{l}0.39 \\
1 \cdot 0 \\
0 \cdot 1 \\
0 \cdot 11\end{array}$ & $\begin{array}{l}0 \cdot 37 \\
0 \cdot 98 \\
0 \cdot 08 \\
0 \cdot 09\end{array}$ & $\begin{array}{l}0.3 \\
0.87 \\
0.43 \\
0.47\end{array}$ & $\begin{array}{l}0.19 \\
0.76 \\
0.22 \\
0.36\end{array}$ & $\begin{array}{l}0 \cdot 0 \\
0 \cdot 07 \\
0 \cdot 0 \\
0 \cdot 0\end{array}$ & $\begin{array}{r}-0.03 \\
0.04 \\
-0.03 \\
-0.03\end{array}$ & $\begin{array}{l}1.95 \\
1.29 \\
0.36 \\
0.25\end{array}$ & $\begin{array}{l}1 \\
1 \\
2 \\
2\end{array}$ \\
\hline Control $^{*}$ & 0.02 & & $0 \cdot 11$ & & 0.03 & . & & \\
\hline
\end{tabular}

*Average of uninfected cell supernatants on each coating immunoglobulin.

ment of $100 \%$ cytopathic effect the viral DNA was extracted with sodium dodecyl sulphate and phenol and precipitated with ethanol. After digestion of the DNA with the enzymes Bst I (Cambridge Biotechnology Laboratories), Pvu II, and Sst I (Bethesda Research Laboratories) the cleavage fragments were resolved by agarose gel electrophoresis and visualised by autoradiography.

\section{ELISA TYPING}

The ELISA typing was carried out without knowledge of the results of the restriction typing. A Dakopatts ELISA HSV typing kit based on the technique described by Vestergaard and Jensen ${ }^{16}$ was kindly provided for evaluation by Mercia Brocades. This kit contained normal rabbit immunoglobulin and rabbit anti-HSV type I (MacIntyre) and rabbit anti-HSV type 2 (MS) antibodies in the form of immunoglobulin fractions obtained by salting out and by ion exchange chromatography. They were absorbed with immobilised fetal calf serum and were supplied unconjugated and conjugated with horseradish peroxidase.

The method used was that described in the kit. Replicate wells of immunological quality microtitre plates (Nunc) were coated at room temperature for $1 \mathrm{~h}$ with normal rabbit immunoglobulin or with antibody to HSV 1 or HSV 2 . Eighty microlitres of each immunoglobulin was diluted in $4 \mathrm{ml}$ coating buffer (0.015 $\left.\mathrm{M} \mathrm{Na}_{2} \mathrm{CO}_{3}, 0.035 \mathrm{M} \mathrm{NaHCO}_{3} ; \mathrm{pH} 9 \cdot 6\right)$ and $100 \mu \mathrm{l}$ of diluted immunoglobulin was used in each well. The plates were then washed five times in wash buffer $\left(0.5 \mathrm{M} \mathrm{NaCl}, 0.0015 \mathrm{M} \mathrm{KH} \mathrm{PO}_{4}\right.$, $0.0065 \mathrm{M} \mathrm{Na}_{2} \mathrm{HPO}_{4} .2 \mathrm{H}_{2} \mathrm{O}, 1 \%$ Triton X-100; pH 7.2).

After washing, $100 \mu \mathrm{l}$ volumes of $1 / 100$ dilutions in dilution buffer (wash buffer containing $1 \%$ bovine serum albumin) of HSV culture supernatant or uninfected cell supernatant were added to one each of the coated wells and incubated at room temperature for $2 \mathrm{~h}$. The plates were washed five times. It was essential to include the uninfected cell control since non-specific binding to anti-HSV 2 was significantly higher than to either anti-HSV 1 or to normal immunoglobulin (Table 1).

After washing, $100 \mu$ l peroxidase conjugated normal immunoglobulin or anti-HSV 1 or 2 immunoglobulin $(80 \mu \mathrm{l}$ stock diluted in $4 \mathrm{ml}$ dilution buffer) was added and incubated for $1 \mathrm{~h}$ at room temperature. The plates were again washed five times.

The plates were then washed once for $1 \mathrm{~min}$ with $100 \mu$ l substrate buffer $(0.0347 \mathrm{M}$ citric acid, $0.0667 \mathrm{M} \mathrm{NaH} \mathrm{PO}_{4} .2 \mathrm{H}_{2} \mathrm{O} ; \mathrm{pH} 5$ ). The substrate, orthophenylenediamine (8 mg OPD and $5 \mu 130 \%$ $\mathrm{H}_{2} \mathrm{O}_{2}$ in $15 \mathrm{ml}$ substrate buffer), was added at $100 \mu \mathrm{l}$ per well and incubated for $15 \mathrm{~min}$ at room temperature. The reaction was stopped with $150 \mu \mathrm{l} M$ $\mathrm{H}_{2} \mathrm{SO}_{4}$, and the absorbances were read.

A negative reaction gives no colour, a heterotypic reaction gives a light brown colour, and a homotypic reaction gives a dark brown colour. A difference in optical density of about 0.2 can easily be detected by eye at the lower range of values $(<1 \cdot 0)$, whereas differences of this magnitude between readings at or above 1.0 can not. In this comparison, however, all reactions were read by an automatic ELISA reader (Dynatech model MR580) interfaced with a Superbrain Microcomputer (Intertec Data Systems) programmed to make the following calculations necessary to ascribe types to the isolates.

For each of the three immunoglobulin specificities average absorbance values with uninfected cell supernatants were calculated and subtracted from the corresponding test absorbances. The test result is positive for the detection of HSV in a given sample if $(a)$ the absorbance of the test well showing the higher absorbance less the absorbance of the normal immunoglobulin control well is greater than $0 \cdot 1$ and (b) the absorbance of that test well is at least twice that of the average control absorbance.

When virus is detected its type is determined by 
dividing the HSV 1 absorbance value by the HSV 2 absorbance value. The isolate is type 1 if the calculated value is greater than 1 , and type 2 if it is less than 1 . Where absorbance values for the two viruses are so close that the result is equivocal, which occurs in about $10 \%$ of tests, a definitive result can be obtained by repeating the test on a more dilute sample of the specimen.

Replicates were not done routinely. Included in each run, however, were type standards, which were always identified correctly and the absorbances of which varied little.

Initially, the four standard strains of HSV were typed by ELISA and then the 39 clinical isolates were tested in the same way.

\section{Results}

The four standard strains of HSV (two each of type 1 and type 2) were correctly and clearly identified by ELISA (Table 1).

The Figure shows the striking and unambiguous differentiation by analysis with the restriction enzyme Bst I of types 1 and 2 in 12 genital isolates of HSV. These and all but one of the remaining clinical isolates were identified correctly by ELISA: of the 39 isolates 10 were type 1 and 28 were type 2 (Table 2). One isolate, however, the profile of which showed specific bands of both HSV 1 and 2, typed by ELISA as HSV 1 or 2 on different occasions. Restriction enzyme analysis of this virus labelled during growth after reisolation or passage showed only a type 1 profile, but analysis of virus labelled during reisolation from the specimen again yielded the mixed profile. This evidence and plaque purification studies (unpublished results) suggest that little type 2 was present and that it was lost on passage.

\section{Discussion}

The results of the ELISA method were unambiguous, and in all but one case correlated completely with restriction enzyme analysis. The single isolate which failed to type satisfactorily by ELISA was clearly a mixture of HSV 1 and 2 and not an intermediate strain, since in addition to yielding mixed profiles its replicate isolates yielded type 1 profiles.

The use of polyclonal antibodies for typing herpes simplex virus gives incorrect results in direct immunofluorescence $^{17}$ and immunoperoxidase ${ }^{18}$ tests, whereas the use of type specific monoclonal antibodies in direct ${ }^{19}$ and in indirect ${ }^{18}$ immunofluorescence correlates completely with restriction enzyme analysis. This suggests that monoclonal antibodies might also be more accurate

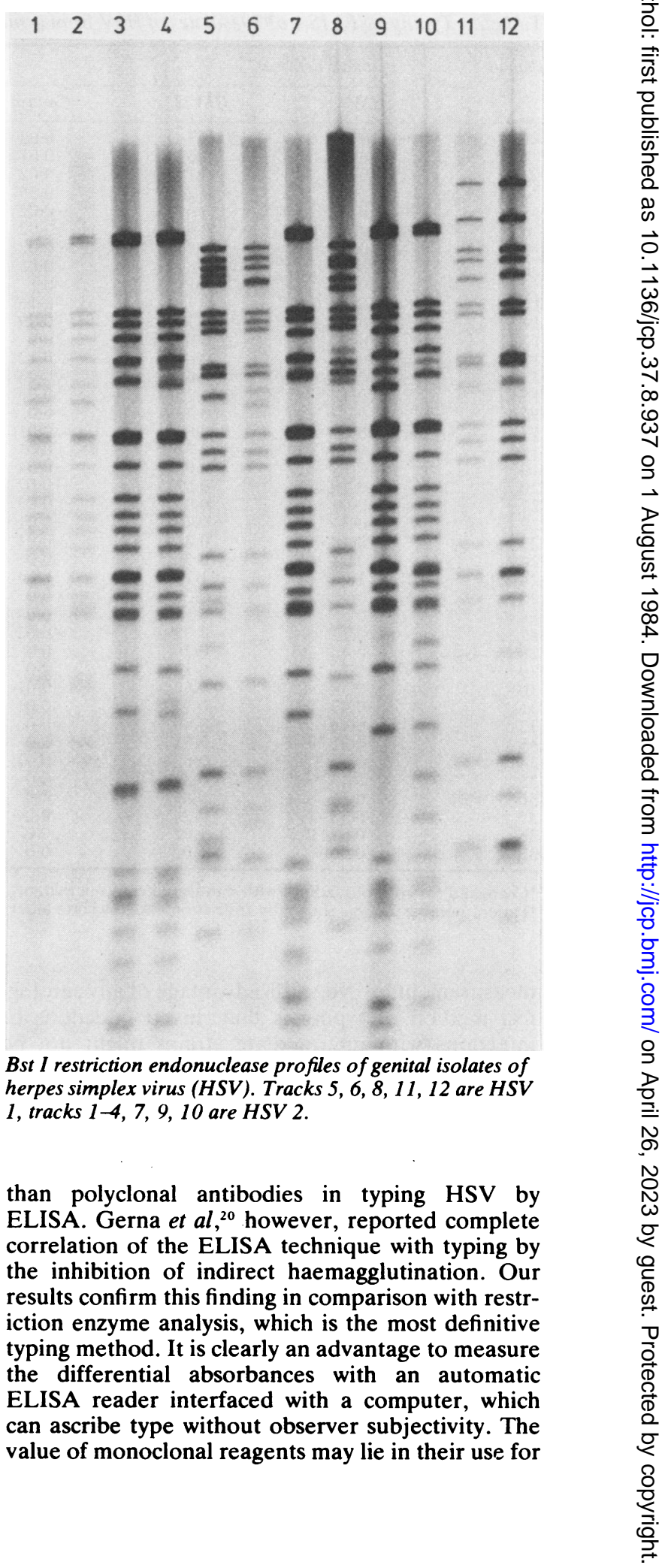


Table 2 Typing by ELISA of 39 isolates of HSV from genital herpes previously typed by restriction endonuclease analysis

\begin{tabular}{|c|c|c|c|c|c|c|}
\hline \multirow[t]{2}{*}{ Patient } & \multicolumn{3}{|c|}{ Optical densities* } & \multirow{2}{*}{$\frac{H S V 1}{H S V 2}$} & \multicolumn{2}{|l|}{ Type } \\
\hline & HSV 1 & HSV 2 & Control & & ELISA & Restriction \\
\hline 1 & 0.09 & $0 \cdot 3$ & -0.02 & $0 \cdot 3$ & 2 & 2 \\
\hline 2 & 0.35 & 0.62 & -0.01 & 0.57 & 2 & 2 \\
\hline 3 & 0.02 & $0 \cdot 18$ & -0.02 & 0.1 & 2 & 2 \\
\hline 4 & $>1.5$ & 0.24 & 0.35 & $>6.25$ & 1 & 1 \\
\hline 5 & 0.16 & 0.62 & -0.02 & 0.26 & 2 & 2 \\
\hline 6 & 0.32 & 0.69 & -0.02 & 0.46 & 2 & 2 \\
\hline 7 & 0.25 & 0.7 & -0.02 & 0.36 & 2 & 2 \\
\hline 8 & 0.9 & $>1 \cdot 5$ & 0.03 & $<0.6$ & 2 & 2 \\
\hline 9 & 0.95 & $>1.5$ & $0 \cdot 1$ & $<0.63$ & 2 & 2 \\
\hline 10 & 0.42 & $0 \cdot 1$ & $0 \cdot 16$ & $4 \cdot 2$ & 1 & 1 \\
\hline 11 & 0.56 & 0.11 & 0.09 & $5 \cdot 1$ & 1 & 1 \\
\hline 12 & 0.8 & 0.32 & $0 \cdot 2$ & $2 \cdot 5$ & 1 & 1 \\
\hline 13 & 0.08 & 0.9 & 0.12 & $0 \cdot 1$ & 2 & 2 \\
\hline 14 & 0.25 & $0 \cdot 6$ & 0.03 & 0.42 & 2 & 2 \\
\hline 15 & 0.4 & 1.23 & 0.06 & 0.33 & 2 & 2 \\
\hline 16 & 0.29 & 0.73 & $0 \cdot 0$ & 0.4 & 2 & 2 \\
\hline 17 & 0.29 & 0.83 & 0.01 & $0 \cdot 35$ & 2 & 2 \\
\hline 18 & 0.07 & 0.39 & 0.01 & 0.18 & 2 & 2 \\
\hline 19 & 0.13 & 0.05 & -0.04 & 2.6 & 1 & 1 \\
\hline 20 & 0.25 & 0.02 & -0.02 & $12 \cdot 5$ & 1 & 1 \\
\hline 21 & 0.03 & 0.9 & 0.03 & 0.03 & 2 & 2 \\
\hline 22 & $0 \cdot 3$ & $0 \cdot 18$ & -0.01 & 1.67 & 1 & 1 \\
\hline 23 & 0.48 & $0 \cdot 3$ & -0.01 & 1.6 & $i$ & 1 \\
\hline 24 & 0.67 & 0.59 & 0.0 & $1 \cdot 14$ & 1 & 1,2 \\
\hline $24 \dagger$ & 1.08 & $1 \cdot 14$ & 0.04 & 0.95 & 2 & 1,2 \\
\hline 25 & 0.48 & 0.27 & 0.0 & 1.78 & 1 & 1 \\
\hline 26 & 0.65 & $0 \cdot 5$ & -0.04 & $1 \cdot 3$ & 1 & 1 \\
\hline 27 & 0.14 & 0.32 & -0.02 & 0.44 & 2 & 2 \\
\hline 28 & 0.46 & 0.7 & 0.0 & $0 \cdot 66$ & $\overline{2}$ & 2 \\
\hline 29 & $0 \cdot 1$ & 0.27 & 0.0 & $0 \cdot 37$ & 2 & 2 \\
\hline 30 & 0.38 & 0.63 & -0.01 & $0 \cdot 6$ & $\overline{2}$ & 2 \\
\hline 31 & 0.47 & 0.74 & 0.01 & $0 \cdot 64$ & 2 & 2 \\
\hline 32 & 0.46 & 0.89 & 0.0 & 0.52 & 2 & 2 \\
\hline 33 & 0.31 & 0.52 & $0 \cdot 0$ & $0 \cdot 6$ & 2 & 2 \\
\hline 34 & 0.39 & 0.6 & -0.02 & 0.65 & 2 & 2 \\
\hline 35 & 0.23 & 0.8 & 0.0 & 0.29 & 2 & 2 \\
\hline 36 & 0.29 & 0.56 & $0 \cdot 0$ & 0.52 & 2 & 2 \\
\hline 37 & 0.35 & 0.54 & 0.0 & 0.65 & 2 & 2 \\
\hline 38 & 0.57 & 1.02 & 0.0 & 0.56 & 2 & 2 \\
\hline 39 & 0.56 & 1.02 & 0.0 & 0.55 & 2 & 2 \\
\hline
\end{tabular}

* Corrected for control readings with uninfected cell supernatants.

†Patient number 24 was shown by restriction endonuclease analysis to be infected with both type 1 and 2 .

measurement by eye. A disadvantage of any serological method of typing is that mixed infections or infections with intermediate strains might not be detected as such. Only one such infection was seen in this series of 39 , however, and none has been detected in any of the other isolates of HSV analysed by restriction endonuclease analysis in this laboratory. Furthermore, mixed infection has not been reported frequently by other workers - thus its incidence is presumably slight.

Further comparison between the two methods must be based on the considerations of simplicity, convenience, cost, and safety. Requiring fewer manipulations, the ELISA technique is easier and more convenient to perform than restriction enzyme analysis; it is also less time consuming and yields results more quickly. Although equivalent in virological safety with restriction enzyme analysis, ELISA does not carry the radiological risks, albeit slight, of the former. A high concentration of detergent is used in dilution and other buffers in order to "solubilise" the antigen; an advantage of this is that viral infectivity is destroyed, making the method virologically safer. The costs of the two methods are about the same. Although restriction enzymes are not cheap, such small quantities of each and of other reagents are used that the cost per test is low.

In conclusion, the ELISA system tested has proved to be as good as restriction endonuclease analysis for the differentiation of the types of herpes simplex virus. It is a safe and easy technique to perform and only if subtyping is required is the latter technique to be preferred.

We thank Mercia Brocades for supplying the ELISA reagents and Dr A Turner for the computer program. 


\section{References}

' Ejercito PM, Kieff ED, Roizman B. Characterization of herpes simplex virus strains differing in their effects on social behaviour of infected cells. J Gen Virol 1968;2:356-64.

${ }^{2}$ Pauls FP, Dowdle WR. A serologic study of herpesvirus hominis strains by microneutralisation tests. J Immunol 1967;98:9417.

${ }^{3}$ Benjamin DR. Rapid typing of herpes simplex virus strains using the indirect immunoperoxidase method. Appl Microbiol 1974;28: 568-71.

4 Kieff ED, Bachenheimer SL, Roizman B. Size, composition and structure of the deoxyribonucleic acid of herpes simplex virus subtypes 1 and $2 . J$ Virol 1971;8:125-32.

${ }^{5}$ Halliburton IW. Biochemical comparisons of type 1 and type 2 herpes simplex virus. In: Biggs PM, de The G, Payne LN, eds. Oncogenesis and herpesviruses. Lyon: International Agency for Research on Cancer, 1972:432-8.

- Schwartz J, Roizman B. Similarities and differences in the development of laboratory strains and freshly isolated strains of herpes simplex virus in HEp-2 cells: electron microscopy. $J$ Virol 1969;4:879-99.

' Pereira L, Cassai E, Honess RW, Roizman B, Terni M, Nahmias A. Variability in the structural polypeptides of herpes simplex virus strains: potential application in molecular epidemiology. Infect Immun 1976; 13:211-20.

${ }^{8}$ Skare J, Summers WP, Summers WC. Structure and function of herpesvirus genomes 1 . Comparison of five HSV-1 and two HSV-2 strains by cleavage of their DNA with Eco RI restriction endonuclease. $J$ Virol 1975;15:726-32.

' Lonsdale DM. A rapid method for distinguishing herpes-simplex virus type 1 from type 2 by restriction enzyme-technology. Lancet 1979; i:849-53.

${ }^{10}$ Buchman TG, Roizman B, Adams G, Stover BH. Restriction endonuclease fingerprinting of herpes simplex virus DNA: a novel epidemiological tool applied to a nosocomial outbreak. J Infect Dis 1978;138:488-98.

"Maitland NJ, Smith IW, Peutherer JF, Robertson DHH, Jones $\mathrm{KW}$. Restriction endonuclease analysis of DNA from genital isolates of herpes simplex virus type 2. Infect Immun $1982 ; 38: 834-42$.
12 Tullo AB, Shimeld C, Easty DL, Darville JM. Distribution of latent herpes virus infection in the human trigeminal ganglion. Lancet 1983; i:353.

${ }^{13}$ Darville JM. A miniaturised and simplified technique for typing and subtyping herpes simplex virus. J Clin Pathol 1983;36:929-34.

${ }^{14}$ Pereira L, Dondero DV, Gallo D, Devlin V, Woodie JD. Serological analysis of herpes simplex virus types 1 and 2 with monoclonal antibodies. Infect Immun 1982;35:363-7.

is Hill TJ, Field HJ, Blyth WA. Acute and recurrent infection with herpes simplex virus: a model for studying latency and recurrent disease. J Gen Virol 1975;28:341-53.

${ }^{16}$ Vestergaard BF, Jensen O. Diagnosis and typing of herpes simplex virus in clinical specimens by the enzyme-linked immunosorbent assay (ELISA). In: Nahmias AJ, Dowdle WR, Schinazi RF, eds. The human herpesviruses. New York: Elsevier, 1981:391-4.

${ }^{17}$ Fife KH, Fife RS, Kleiman MB, French MLV. Incorrect typing of herpes simplex virus isolates by direct immunofluorescence. $J$ Infect Dis 1983;148:338.

${ }^{18}$ Peterson E, Schmidt OW, Goldstein LC, Nowinski RC, Corey L. Typing of herpes simplex virus isolates with mouse monoclonal antibodies to herpes simplex virus type 1 and 2: comparison with type-specific rabbit antisera and restriction endonuclease analysis of viral DNA. J Clin Microbiol 1983;17:92-6.

${ }^{14}$ Volpi A, Lakeman AD, Pereira L, Stagno S. Monoclonal antibodies for rapid diagnosis and typing of genital herpes infections during pregnancy. Am J Obstet Gynecol 1983;146:8135 .

${ }^{20}$ Gerna G, Battaglia M, Revello MG, Gerna MT. Typing of herpes simplex virus isolates by enzyme-linked immunosorbent assay: comparison between indirect and double-antibody sandwich techniques. J Clin Microbiol 1983;17:942-4.

Requests for reprints to: Dr JM Darville, Department of Virology, Bristol Royal Infirmary, Marlborough Street, Bristol BS2 8HW England. 